\title{
О.Б. Элькан
}

\section{ФЕНОМЕН «ГОВОРЯЩИХ» ИМЕН СОБСТВЕННЫХ В ОНОМАСФЕРЕ НЕМЕЦКОЯЗЫЧНОЙ КУЛЬТУРЫ ХХ В. (НА ПРИМЕРЕ РОМАНА Г. ГЕССЕ «ИГРА В БИСЕР»)}

\begin{abstract}
Осуществлено ассочиативное и этимологическое исследование гессевского "ономастикона», представленного важнейшими в творчестве данного автора именами собственными - фамилией главного героя «Игры в бисер» Кнехта и названием странь Касталия, в которой происходят основные события романа. Эти собственные имена со времени выхода романа в свет стали нарицательными и впоследствии заняли столь же важное положение в общей «ономасфере» немечкоязычной культуры ХХ в. Проведенный автором статьи «этимологический экскурс» выявляет их «синтетиче ский» характер, выразившийся в глубоком полисемантизме и неоднозначности возможной трактовки.

Ключевые слова: культура ХХ века, ономасфера, ономастикон, Г. Гессе.
\end{abstract}

Герман Гессе, немецкий и швейцарский писатель, поэт и художник, родился в 1877 г. в Кальве, одном из административных центров немецкой земли Баден-Вюртемберг. В 1919 г. в знак протеста против проявлений германского милитаризма в Первой мировой войне Гессе переехал в Швейцарию, где жил в добровольном изгнании до самой смерти в 1962 г. Антимилитаристский - а позднее и антинацистский - мотив станет со временем одним из лейтмотивов всей его духовной и творческой биографии.

Наиболее популярные его работы - «Степной волк», «Сиддхартха», «Нарцисс и Гольдмунд» (в другом переводе «Нарцисс и Златоуст»), «Паломничество в страну Востока» и, наконец, главный и заключительный труд его жизни - «Игра в бисер» (нем. Das Glasperlenspiel), над которой автор работал в течение двенадцати лет. В 1946 г. именно этот роман был удостоен Нобелевской премии по литературе с формулировкой «За вдохновенное творчество, в котором проявляются классические идеалы гуманизма, а также за блестящий стиль».

Основная часть романа написана в жанре так называемой «псевдобиографии», представляя собой подробное и с максимально возможным правдоподобием воссозданное жизнеописание вымышленного персонажа - Иозефа Кнехта, «Магистра» той самой «Игры в бисер», название которой служит одновременно и названием всего произведения.

В центре сюжетной канвы романа - жизнь Иозефа Кнехта, история его иерархического восхождения к статусу Магистра Игры в бисер (для всех прочих игроков Магистр Игры - «князь, первосвященник, почти божество»!.. [1]). Отслужив в течение многих лет в качестве одного из наиболее блестящих магистров за всю историю Игры, Кнехт переживает серьезный психологический кризис, постепенно приходя к осознанию тщетности попыток укрыться от реального мира даже в таком высокодуховном и аристо- 
кратическом убежище, как Игра и Касталия, элитарная провинция «мастеров духа». В итоге Кнехт решает оставить Касталию и Игру и продолжить свою жизнь «в миру», служа частным учителем в доме своего друга и бывшего оппонента Плинио Дезиньори. Однако едва ли не в первый же день своей новой жизни Кнехт на глазах своего ученика, сына Плинио Тито, тонет в холодном альпийском озере, лелеемый теплыми лучами восходящего солнца.

Всей работе предпослано популярное введение в сущность и историю Игры, так и озаглавленное: «Игра в бисер. Опыт общепонятного введения в ее историю».

В первую очередь, конечно, обращает на себя внимание использованный автором термин «игра» (нем. Spiel). Само слово «игра», вопреки общей «солидности» и даже некоторой патетичности всего повествования в целом, а также вопреки постоянно подчеркиваемому благоговению и пиетету, испытываемому в отношении Игры не только ее адептами, но даже, в определенной мере, сторонними наблюдателями, - словно бы намекает на не слишком серьезный характер данного установления. И действительно, история Игры развивается, начиная с использования неких ее достаточно примитивных еще «предтеч» в качестве досужей забавы математиков и / или музыкантов, ни к чему не обязывающего интеллектуального развлечения. Со временем формы Игры усложняются, принимая все более изощренный и элитарный характер, - но не остается ли она и в последующем все той же забавой для горстки избранных интеллектуалов либо же действительно, как полагают сами эти «избранные», призвана служить сохранению некоторого базового уровня духовности в быстро меняющемся и подверженном самым разнообразным катаклизмам мире?.. Как сформулировал один из комментаторов романа Е. Маркович, Гессе словно бы специально задается вопросом: «Действительно, всего лишь игра или жизненная необходимость? А может быть, разновидность новой религии для интеллектуалов? Чему должна служить духовная деятельность, чтобы не превратиться в пустую игру?..» [1].

Согласно же наиболее радикальному истолкованию филолога-германиста Теодора Циолковского, первого американского переводчика «Игры в бисер» и одного из наиболее авторитетных англоязычных исследователей творчества Гессе, никакого вопроса здесь просто нет: автор романа изначально задает шутливый, иронический тон, сам предлагая читателю забавную игру, лишь на поверхностный взгляд представляющую действительно серьезное и проблемное повествование. «В Германии, - писал Циолковский, - многие читатели [...] видят в культурной провинции, созданной Гессе, только лишь утопию бегства от суровых послевоенных реалий. Более проницательные же европейские критики, как правило, были так увлечены модными “серьезными” намеками и аллюзиями, щедро рассыпанными по тексту романа, что упустили возможность посмеяться над юмором Гессе и улыбнуться его парадоксам» [2. С. 7].

Это, повторим, позиция наиболее радикальная; основная часть «более проницательных европейских критиков» не разделяет ее. Согласно общему мнению, сам вопрос, естественно возникающий по отношению к использованию Гессе термина «игра», по ходу изложения оказывается основным вопро- 
сом и основным конфликтом произведения, его лейтмотивом, разрабатываемым с почти музыкальной последовательностью и выразительностью.

Следующий важный момент - как раз элитарность как самой игры и игроков, так и шире - особой «высокодуховной» Провинции, названной Гессе Касталией. «Касталия - это особое маленькое государство», а содружество городов «игроков в бисер» в рамках этого государства - «маленькая, но старая и гордая республика, однотипная и равноправная со своими сестрами, но укрепленная и возвышенная в сознании собственного достоинства особым эстетическим и в некотором роде священным характером своей деятельности» [1]. Рассказчик говорит о ней как об «укромнейшей и приветливейшей области нашей горной страны (страны, также вымышленной самим Гессе и существующей в далеком XXV столетии, но многими приметами напоминающей современную автору Германию и Швейцарию. - О.Э.), которую раньше часто называли также, пользуясь термином писателя Гете, "Педагогической Провинцией”» [Там же]. Гете был одним из наиболее любимых и авторитетных для Гессе авторов, оказавшим серьезное влияние на все его творчество; не случайно в том же 1946 г., когда Гессе становится лауреатом Нобелевской премии, он завоевывает и очень престижную в среде немецких литераторов «премию Гете». «Педагогическую провинцию» Гете из его романа «Годы странствий Вильгельма Мейстера» часто называют литературным прототипом или классическим прообразом Касталии - с существенной, правда, оговоркой: «...если перед адептами Педагогической провинции Гете “открываются неизмеримые поприща деятельности”, то служители Касталии добровольно замыкаются в границы культурного микрокосмоса» [Там же]).

Здесь обитают не только приверженцы Игры в бисер, составляющие, так сказать, «элиту в элите», верхние страты касталийского социума; в первую очередь Касталия - своеобразное «гнездо» особых элитных школ, выпускники которых составляют ядро педагогического состава учебных заведений всей страны. «Касталия воспитывает превосходных музыкантов и искусствоведов, филологов, математиков и других ученых» [Там же]). Провинция управляется строго иерархичной системой, причем высшая власть в Касталии разделена между представителями, с одной стороны, Педагогического ведомства, с другой - самыми квалифицированными и выдающимися мастерами Игры в бисер.

«Игра в бисер» - интеллектуальный отклик автора на варварские реалии гитлеровского фашизма. Соответственно, педагогическая утопия Касталии представляет собой выраженный в художественной форме проект альтернативы диктатуре и преступлениям Третьего рейха, но также и вневременное исследование новых возможностей формирования интеллектуальной элиты нации. Автономный мир духовной дисциплины и аскетизма в Касталии находит высшее выражение и завершение в искусстве Игры в бисер. «Гессе сам говорил, что Касталия была его отповедью фашизму, попыткой восславить духовность в “чумном, отравленном мире"» [Там же]: «В этой атмосфере, угрожавшей физическому и духовному существованию немецкоязычного поэта, я прибег к спасительному средству художников - к творчеству...», пишет Г. Гессе о работе над романом [3. С. 208]; в образе Касталии он буквально находит мир, чья атмосфера все еще пригодна для дыхания. Одновре- 
менно писатель понимает проблему спасения духовного начала в мире таким образом, что оно требует от истинной интеллигенции «покинуть свою изолированную Касталию (иными словами, все ту же пресловутую “башню из слоновой кости”) и обрести свое “служение” в мире практики» [1].

Самый простой контент-анализ обнаруживает, что слова с корнем «элит» встречаются в тексте романа... 149 раз! В основном речь идет об «элитных (касталийских. - O.Э.) школах» и «элитных учениках», но также и в целом о касталийской же «элите», «духовной» и «высокодуховной элите», «элитном мире» Касталии, «касталийских элитах», «элитарной Провинции» и т.д. Девять раз встречается и родственное слову «элита» латинское electus - «избранный» или electi - «избранные», что для немецкоязычного текста также весьма высокий показатель.

Гипотеза нашего исследования такова: в индивидуальной семиосфере творчества Г. Гессе формируется некий существенный элемент, который мы вправе были бы назвать «ономастиконом» (ономастика, от греч. опота -

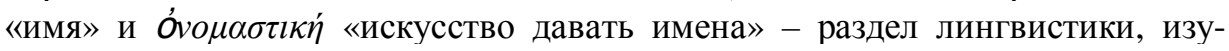
чающий историю и трансформацию имен собственных) - сферой значимых имен собственных в качестве столь же значимых сигнатур, или знаков. В более привычном понимании «ономастикон», или «именослов», означает словарь имен конкретного языка или народа. Индивидуальные литературноавторские ономастиконы, в свою очередь, объединяясь с другими подобными, образуют общую для данной семиосферы «ономасферу» - сферу значимых в рамках данной семиосферы имён.

В связи с этим рассмотрим внимательней гессевский топоним «Касталия». Общепринятое толкование резонно прочитывает в нем явную аллюзию на Кастальский ключ на Парнасе, источник вдохновения для поэтов и музыкантов. Именно эту аллюзию, безусловно, имел в виду и сам Гессе; однако, насколько нам известно, никто из исследователей пока не пытался проникнуть несколько глубже этого почти самоочевидного уровня прочтения термина, имея в виду его возможную полисемию, высочайший культурнообразовательный уровень автора и не в последнюю очередь даже, возможно, опыт, полученный им в свое время в качестве пациента сначала ученика и сподвижника Юнга Йозефа Ланга, а затем и самого Карла-Густава Юнга, идеями которого он был весьма впечатлен (см. подробнее 4) и один из ключевых подходов которого к аналитической терапии составлял, как известно, знаменитый юнговский «метод свободных ассоциаций».

Попробуем восполнить этот пробел. Наиболее отчетливой ассоциацией со словом «Касталия» в исследуемом отношении выступает, вероятно, слово «каста». Так, Н.В. Бороденко прямо говорит о «касталийстве» «как части касте - общего мира, отделенной от основного массива жизни» [5. С. 999] (не увязывая, однако, напрямую термины «Касталия» и «каста»); слово «каста» даже присутствует и в тексте романа: «... Плинио называет наших жителей и наставников кастой жрецов...» [1]. Ассоциативный ряд продолжает общеевропейский термин, несомненно, хорошо знакомый Гессе и восходящий к латинскому castellum - «замок», «форт», «крепость», «цитадель»: нем. das Kastell, фp. chastel и château, англ. castle (например, известный слоган «My home is my castle», на русский обычно переводимый как «Мой дом - моя 
крепость»), исп. castillo. Последнее из перечисленных слов, в частности, легло в основу названия центрального региона Испании - Кастилии: считается, что оно говорило о множестве замков и крепостей, выстроенных кастильцами для защиты от мусульманских завоевателей. Сходство топонимов «Касталия» и «Кастилия» бросается в глаза, и Гессе, очевидно, вполне мог иметь в виду и эту аллюзию. В то же время указанные родственные слова, означающие «замок» или «крепость», вызывают в памяти слово из того же ассоциативного ряда - «башня», по-немецки der Turm. Если Педагогическая провинция из «Вильгельма Мейстера» Гете послужила «литературным прототипом» Касталии, - таинственное «Общество Башни» (die Turmgesellschaft) из того же романа стало, вероятно, таким же «прообразом» не менее таинственного касталийского Ордена...

Ассоциация с «замком» и «башней», в свою очередь, может быть связана и с фамилией главного героя - Кнехт. Der Knecht в переводе с немецкого означает не только «слуга», но имеет также и более уничижительные значения - такие, как «холоп», «лакей», «батрак», «раб». Гессе - очень склонный, по словам Т. Циолковского, к «ономастически-комедийным» [2. С. 8] изыскам и изысканиям, - намеренно выбирает это слово фамилией своего героя, имея в виду в первую очередь мотив «служения», воплощенный в романе в образе Иозефа Кнехта. В данном случае фамилия и официальный титул героя избраны «по контрасту» и одновременно «по созвучию» с фамилией все того же гетевского Вильгельма Мейстера: нем. der Meister - «хозяин», «господин», «повелитель», но также и «магистр» (титул Иозефа Кнехта, как одного из касталийских иерархов, - Magister Ludi, т.е. «Магистр Игры»...) Продолжая это противопоставление, Гессе дает главному антагонисту и оппоненту, «другу-врагу» Кнехта Плинио, дискуссия Кнехта с которым (или «диалог-диспут», по выражению Н.В. Бороденко [6. С. 1445]) продолжается на всем протяжении романа и выражает основной его конфликт и лейтмотив, еще одну «говорящую» фамилию: Дезиньори (ит. de signori, «из господ»). За обоими мы наблюдаем начиная с детских лет: Иозеф, юный сирота, жизнь которого по его собственному признанию «уже неотделима от Касталии» [1], оказывается одним из ее самых блестящих и перспективных «элитных учеников» - и вынужден по повелению свыше взять на себя тяжелую, но благородную миссию: утверждать и отстаивать касталийские идеалы перед Плинио, сыном аристократов и касталийским вольнослушателем, который относится к вышеозначенным идеалам довольно скептически - видя в них бегство от реальности в пресловутую «башню из слоновой кости».

Представляется, однако, что Гессе мог подразумевать также и следующую ассоциацию, возникающую в сознании любого образованного читателя: да, Knecht по-немецки «слуга», но родственное, фактически даже однокоренное ему слово в некоторых других германских языках - англ., ирл., валлийск., исл. knight - переводится как «рыцарь». Что снова возвращает нас в семантическое поле «замков» и «крепостей»: Кнехт - верный рыцарь и служитель касталийской цитадели (Kastell, castel, chastel, castle). Показательно, что сам Гессе еще в 1927 г. определял главной задачей настоящего писателя «быть служителем, адвокатом и рыцарем души» (цит. по: [7. С. 17]). 
Наш этимологический экскурс будет неполным, если мы не проследим историю слов, подобных словам Knecht и knight, еще дальше вглубь времен. Они восходят к одному из древнейших протоиндоевропейских корней - gn / kn, с которым наиболее тесно связаны три основные группы значений:

- Род, рождение, порождение, родственные связи. Из современных «потомков» этого корня первым делом приходит на ум, конечно, греческий корень «ген»: «гены», «генетика», «генетический», «генезис», а также англ. kin - «родня» и kind - «ребенок», нем. Das Kind с тем же значением, греч.

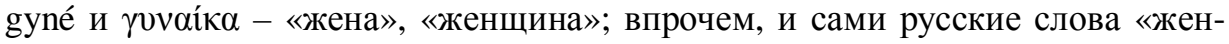
щина» и «жена» имеют то же происхождение; наконец, то же самое происхождение имеют и Der Knecht, и knight: их «предки» в различных германских языках древности и средневековья - ст.-англ. cniht, фриз. kniucht, дат. и ср.герм. kneht - означали «младшего члена семьи», «мальчика», «юношу», «слугу». Легко прослеживается генезис понятия в Der Knecht, «слуга», и отсюда уже в knight - «рыцарь» в значении в первую очередь «вассал», «слуга своего сюзерена».

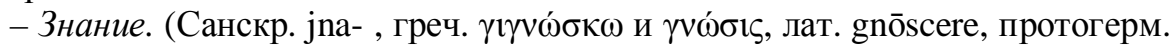
knew, англ. know, нем. kennen и kennt, рус. знать).

- Знатность. (Протогерм. kuningaz, ст.-англ. суning, ст.-норв. konungr, нем. Der König, англ. king, рус. князь). «Совпадение» слов «знание» и «знатность» здесь не случайно: лидерами древних обществ традиционно становились люди, представляющие жреческое сословие и на этом основании обладающие неким «магическим» знанием, в силу чего именно они считались достойными и способными руководить своими общинами. Великий культуролог Дж. Дж. Фрэзер, метко определивший эту «касту» как «царей-жрецов», писал о ней: «...сочетание жреческих функций с царской властью известно повсеместно... В те времена божественность, окутывающая царя, была не пустой фразой, а выражением твердой веры» [8. С. 99].

Здесь уместно обратить внимание и на многозначность родственного слову «магистр» (титул Кнехта) современного понятия master в английском языке: “мастер” (как человек, обладающий высокой компетентностью в какойлибо сфере деятельности), “господин”, “учитель” и т.д. Это слово и родственные ему слова других европейских языков происходят от лат magister: в первоначальном значении - “больший, лучший”, от лат. magis - “больше”, родственного, в свою очередь, латинскому magnus, греческому $\mu \varepsilon_{\gamma} \alpha \varsigma$ (mégas), санскритскому mahá - все в значении "великий” - и сохранившемуся в современном английском much - “много”. Развитие романного сюжета и образа Кнехта у Гессе удивительно удачно может проиллюстрировать эту динамику: в то время как его вечный антагонист Плинио Дезиньори («из господ») во «внешнем» мире делает в целом неплохую, но совсем не экстраординарную карьеру политического деятеля средней руки, «слуга» Кнехт, бывший безвестный сирота, достигает одной из самых высших ступеней сложной касталийской иерархии именно с помощью накопленного им колоссального массива всевозможных знаний и умений.

Отметим еще одно ответвление ассоциативного ряда, связанное с духовной стороной Игры. Если этимология греческого названия Кастальского источника неизвестна (согласно Павсанию: «Иные предпочитают придержи- 
ваться сказания, что был местный житель, Касталий (äv $\delta \rho \alpha \alpha$ Útó $\chi \theta o v \alpha$

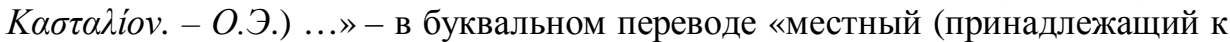
коренному населению. - О.Э.) мужчина» [9. С. 333], в классическом труде А.Ф. Лосева «Античная мифология в ее историческом развитии» использован

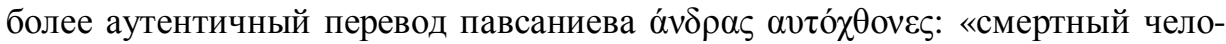
век Касталий, “рожденный Землей”» [10. С. 360]; в более поздних источниках упоминается нимфа Касталия, бросившаяся в источник с целью избежать домогательств Аполлона, но что означали имена Касталий или Касталия, вряд ли можно утверждать безоговорочно), - то происхождение представленных выше понятий, таких как «каста» или слова, обозначающие «замок» и «крепость», вполне прозрачно. Все они имеют общую этимологию, восходя к протоиндоевропейскому корню kes- («резать», «отрезать», «отсекать»): отсюда и англ. cut, и, по нашему мнению, русские слова «часть», «кусать», «участь» и «счастье» («со-частье», «своя часть», «своя участь»). Но современные европейские слова восходят к данному корню в основном «через» средневековую и античную латынь, в которой он представлен, в частности, такими словами, как castus («нравственно чистый, невинный, целомудренный, благочестивый, набожный, бескорыстный»), castitas и castimentia («телесная чистота, чистота нравов, нравственность, целомудрие»). Мы полагаем

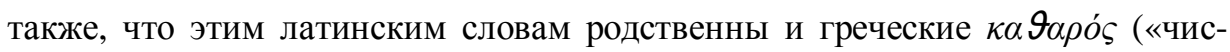
тый») и ка́ $\theta \alpha \rho \sigma l \varsigma$ (катарсис, «очищение»).

Этот аспект как нельзя лучше характеризует и «касту» «рыцарей» кастальского «замка». Игра в бисер есть некий «всемирный язык людей духа» [1], она требует «глубокой и душевной самоотдачи» [Там же]; во время ежегодных публичных Игр «участники и слушатели живут по строгим инструкциям, определяющим даже продолжительность сна, воздержанной и самоотверженной жизнью абсолютного отрешения от мира, похожей на строго регламентированную, аскетическую жизнь, какую вели участники радений святого Игнатия» [Там же]; рассказчик упоминает даже своего рода «поворот к религиозности», свершившийся некогда в истории Игры [Там же], которая с тех пор уже «означала изысканную, символическую форму поисков совершенного, возвышенную алхимию, приближение к внутренне единому над всеми его ипостасями духу, а значит - к богу. Подобно тому, как религиозные мыслители прежних времен представляли себе жизнь тварей живых дорогой к богу и только в божественном единстве усматривали полную завершенность многообразного мира явлений, - примерно так же фигуры и формулы Игры [Там же] устремлялись, играя, к совершенству, к чистому бытию, к сбывшейся целиком действительности...» [Там же]. Адепты Игры являются членами некоего таинственного Ордена, весьма схожего с религиозными орденами монахов-рыцарей (госпитальеров, тамплиеров, иоаннитов и др.). Их отличают аскетизм, строгая дисциплина и повиновение, полное подчинение личности иерархическому принципу, безбрачие и вообще несвязанность семейными узами. Все жители Касталии - мастера и специалисты в избранных ими областях науки и искусства - еще в раннем возрасте прошли тщательный отбор и живут фактически вне времени и истории, в условиях, максимально способствующих их духовному и профессиональному развитию, но почти не оставляющих места для того, что за касталийскими преде- 
лами принято считать собственно жизнью: они не стремятся к деньгам, славе, жизненному успеху, не заводят семей или любовных связей; во всем романе мы практически не встречаем женских образов.

Наводит на определенные размышления также родство всего ряда указанных понятий и с латинским castro («оскопить, холостить, кастрировать», в переносном смысле - «ослаблять») - прямым, кстати говоря, «предком» тех терминов из вышеприведенного ряда, которые связаны с понятиями «чистоты», «нравственности», «целомудрия». Еще любопытней, пожалуй, что и в одном из фрагментов текста романа Гессе слова «каста» и «кастрировать» тоже оказываются соседями - позволим себе вновь процитировать и продолжить это место из письма Кнехта Магистру музыки, в котором он ссылается на Плинио, называвшего «наших жителей и наставников кастой жрецов, а нас, учеников, - их покорной, кастрированной паствой...» [Там же].

В очередной раз наша мысль, развиваясь по спирали, возвращается к проблеме, которую мы обозначили как лейтмотивную для всего романа Гессе: не представляет ли собой Игра в бисер нечто, как пытался убедить Кнехта Плинио, в определенном смысле «выхолащивающее» и «оскопляющее» сознание, лишая его грандиозной части человеческого опыта - мирских страстей, повседневных забот, борьбы за существование и место под солнцем?.. - Гессе, как это принято у великих писателей, не дает однозначного ответа на им же поставленный вопрос. Необходимость формирования собственной позиции по этому вопросу - повод для наших дальнейших научных изысканий за пределами настоящей статьи.

Пока же вне рамок нашего рассмотрения осталось «главное» имя в творчестве Гессе - имя главного героя его главного романа, «Игра в бисер», - Иозеф. Зная пристрастие Гессе к «говорящим» именам, сложно представить, что именно это имя было выбрано случайно и не несет на себе никакой дополнительной семиотической нагрузки. Ведь Гессе, как мы уже убедились, принадлежит к авторам, в индивидуальной семиосфере творчества которых значительная роль принадлежит индивидуальному же ономастикону. Так, «Касталия» и «Кнехт», будучи важными элементами гессевского ономастикона, в то же время представляют и не менее важные элементы общей ономасферы в рамках семиосферы немецкоязычной культуры XX в. Что же касается имени Иозеф - оно, по нашему мнению, остается более «личным», поскольку его протоним, с одной стороны, действительно играл важную (может быть, важнейшую!) роль в жизни Гессе, с другой же стороны, именно этого человека до сих пор в научных работах пока не рассматривали именно как протонима Иозефа [Кнехта] из «Игры в бисер». Мы говорим сейчас о человеке, сыгравшем действительно колоссальную роль в жизни Гессе: одновременно роль его задушевного друга, врача, учителя, доверенного лица и общепризнанного прототипа нескольких персонажей более ранних произведений Гессе, - о Йозефе Ланге.

Йозеф Бернард Ланг (1883-1945) - известный немецко-австрийский психоаналитик, ученик Карла-Густава Юнга. В первый период их знакомства он действительно был для Гессе в первую очередь терапевтом-психоаналитиком, но очень скоро их отношения стали по-настоящему близкими. «Доктор и друг - вот лейтмотив отношений между Гессе и Лангом» [11. С. 92]. 
Герман Гессе активно интересовался психоанализом. Он посвятил этому учению книгу «Фрейд» и статью «Художник и психоанализ»; влияние теорий Фрейда исследователи находят во многих его произведениях (см., например, [12. С. 27]). Особо привлекала его тема сновидений и их интерпретации в психоанализе; многие его творения в той или иной степени связаны и с этой темой. Ей отдается дань и в «главном» романе Гессе, «Игра в бисер»; достаточно вспомнить сон Кнехта о музыке и его интерпретацию Магистром музыки - эпизод, крайне важный для понимания всего романа. Однако в жизни Гессе все-таки больше склонялся к учению К.-Г. Юнга. Интересно, что известное юнгианское общество, ставящее своей задачей распространение в русскоязычной среде наиболее значимых работ по аналитической психологии, называется «Касталия»: «"Касталия" - просветительский проект, целью которого является ознакомление заинтересованной русскоязычной аудитории с зарубежными исследованиями в таких областях, как западный эзотеризм, психология глубин, символическое измерение в искусстве. Основной приоритет нашей деятельности - изучение наследия Карла Густава Юнга...» [13].

В частности, участники «Касталии» перевели на русский знаменитую рукописную «Красную книгу» Юнга (прекрасный пример того, как лучшие образцы человеческой культуры взаимно питают друг друга: последователи Юнга, чьи идеи так плодотворно развивал в своем творчестве Гессе, для названия своего общества воспользовались изобретенным Гессе символом...).

Юнгианцем был и психотерапевт Йозеф Ланг, к помощи которого Гессе обращался неоднократно в самые критические периоды своей жизни. Впервые это случилось в 1916 г. Этот период - один из наиболее драматичных в жизни Гессе. Первая мировая война, против которой так восставал дух Гессе - нужно помнить при этом, что на родине его считали предателем Германии; смерть отца, Иоганна Гессе, тяжелая болезнь сына Мартина; серьезное психическое заболевание первой жены, Марии Гессе-Бернулли, и ее госпитализация в психиатрическую лечебницу; возникшие в связи с этим юридические проблемы устройства детей, которых требовалось разместить у друзей семьи либо в детских домах, - весь этот туго затянутый клубок жизненных неурядиц вверг будущего автора «Игры в бисер» в состояние глубокой депрессии, к которой он вообще был наследственно склонен. (В юности он уже совершил попытку самоубийства.) Единственным возможным выходом оказывается психотерапия - и Йозеф Ланг, к которому обращается за помощью Гессе, блестяще справляется с задачей помочь писателю преодолеть этот кризисный период. С подачи Ланга Гессе близко знакомится с юнгианской концепцией; однако сам Юнг - несмотря на то, что позднее Гессе лично познакомится и подружится с ним, а также пройдет курс психотерапии в 1921 г. в Цюрихе у самого мэтра аналитической психологии, - все же никогда не будет иметь для него такое огромное значение, как Ланг. В 1916-1917 гг. Гессе проходит у Ланга 60 трехчасовых сеансов. До 1945 г., года смерти Ланга, эти двое остаются близкими друзьями и ведут активную переписку - иногда по несколько писем в день. Йозеф Ланг, в рамках учения Юнга, «переоткрыл» для Гессе Восток, к которому тот и сам был с детства неравнодушен; Ланг побудил его, в рамках психотерапии, заняться живописью и музыкой (с последней, впрочем, у Гессе тоже были тесные «интимные» отношения и до 
Ланга. Добавим здесь, что арт-терапию - терапию живописью - вполне резонно возводят к методам и методикам Юнга; рукописная «Красная книга» самого Юнга буквально пестрит его собственными рисунками, в которых мэтр аналитической психологии отображал образы, всплывающие из бессознательного и обретающие вполне «объективное» существование). Ланг опять же с позиций юнгианства - подвиг Гессе, а вслед за тем, естественно, и его героев на поиск «Самости», «индивидуации», «собственного пути»: отныне и этот мотив переходит в разряд лейтмотивов творчества Гессе. (В 1917 г., «в разгар» сеансов с Лангом, Гессе пишет в частном письме: «Путь к себе более священен, чем все буржуазные идеалы...» (цит. по: [14. С. 128]). Само «Жизнеописание» Иозефа Кнехта в «Игре в бисер», по общему признанию исследователей, представляет собой не что иное, как «процесс индивидуации, заключающийся в продвижении “внешней личности” к психическому центру индивидуальности, называемому [Юнгом. - О.Э.] “Самостью”» [15. С. 121].

«Ланг приглашал друга “прислушаться к голосу первозданных глубин”. Через хаос в душе своего пациента он открывал в нем скрытые возможности. Так в Германе зрело новое сильное, прекрасное творческое начало. Он стремился к космосу, зная, что тот, кто постигнет его сумрак, обретет истину...» [Там же].

«Плодом» первого этапа общения Гессе и Йозефа Ланга стал, безусловно, «Демиан» (1919) - роман, изданный Гессе под псевдонимом Синклер. «"Демиан" - произведение Гессе, где сильно отразилось влияние Ланга. Эта книга - их совместная попытка избавиться от того, что стесняет человеческую душу, “выйти из яйца”, достичь глубин души и сознания. Отважное предприятие, заставившее воскреснуть в писателе юность, связанную для него с мучительным поиском своего предназначения...» [15. С. 129].

Ланг находит в «Демиане» и свое «литературное воплощение»: это Писториус, один из центральных персонажей романа. «То, что Гессе в образе Писториуса воздвиг литературный памятник своему другу и психотерапевту И.Б. Лангу, известно всему миру» [16], - пишет Гюнтер Бауман, один из наиболее известных исследователей в сфере проявлений юнгианства в творчестве Гессе. Ж. и М. Сенэс, авторы романизированной биографии «Герман Гессе, или Жизнь Мага», подтверждают: «...в “Демиане” Писториус литературное воплощение доктора Ланга» [14. С. 129].

Другое «литературное воплощение» Ланга - астролог Лонг из предпоследнего, непосредственно предшествовавшего «Игре в бисер» романа Гессе «Паломничество в страну Востока», тоже персонаж далеко не из последних. («Я отыскал Лонга, он сидел в роще с пергаментной книгой на коленях и писал в нее греческие и еврейские знаки: слова, из букв которых вылетали драконы и поднимались пестрые змеи...» [17. С. 166] - вот самый типичный его портрет в книге, и загадочные «письмена» Лонга оказываются важнейшим в системе ее символов). Действительно, Ланг, как и его учитель Юнг, серьезно увлекался астрологией наряду со многими прочими «древними» и «восточными» темами, к которым он приохотил и Гессе.

Таким образом, именно психотерапевт и близкий друг Гессе Йозеф Ланг послужил прототипом Писториуса в «Демиане», астролога Лонга в «Палом- 
ничестве в страну Востока» и - в чем мы глубоко убеждены - также протонимом Иозефа Кнехта в «Игре в бисер».

Мы можем найти этому предположению и довольно неожиданное подтверждение. Поначалу широкая публика знала об отношениях Гессе и Ланга из первой биографии Гессе, написанной другим его другом - поэтом, журналистом, драматургом, одним из «отцов» дадаизма Хуго Баллем. Картина, нарисованная Баллем, ничем не отличалась от уже воспроизведенной нами: Гессе - наследственный невротик, переживающий духовный и жизненный кризис один за другим, Ланг - талантливый психотерапевт и близкий друг, сумевший помочь писателю выбраться из экзистенциальной бездны [18]. Однако Балль погиб в 1927 г., и его биография Гессе заканчивается тем же годом; он не мог знать, как драматично будут развиваться эти отношения.

Предоставим слово другому биографу Гессе (на сегодня наиболее авторитетному его биографу и библиографу) Дж. Милеку: «Ланг [...] был очень талантливым терапевтом - но он был также весьма эксцентричен и неудачлив; его карьера, столь многообещающая, в итоге не задалась. По мере того как профессиональные и личные обстоятельства его жизни менялись от “плохого” к “худшему”, он оказывается все более зависим от Гессе (в эмоциональном плане. - О.Э.). К сороковым годам распределение ролей в их дружеском тандеме кардинально изменилось...» [19. С. 67].

В комментариях к переписке Гессе и Ланга, изданной в Германии, называется еще более ранняя дата этого «перелома». «В течение 1920-х годов преобладают личные проблемы Ланга, и они становятся доминирующей темой в его письмах к Гессе. Ланг чувствует себя непонятым женой и в 1920 году заводит короткий, но чрезвычайно страстный роман с Рут Венгер (в 1924 Рут станет второй женой Гессе, но и этот брак скоро распадется). Он часто болеет, жалуется на желчные колики или проблемы с сердцем. Особенно же его заботят постоянные проблемы с деньгами и, прежде всего, профессиональная неудовлетворенность - Ланг выражает желание “повесить врачебный халат на гвоздь" и посвятить себя искусству или научным исследованиям» [11. С. 92].

«В течение третьего брака, - утверждает Гюнтер Бауман, - жизнь Гессе окончательно стабилизировалась, так что он не нуждался больше ни в какой психологической поддержке [...] Примерно с 1927 года Гессе становится другом и советчиком для тяжело больного Ланга и может с лихвой отплатить ему за полученную в свое время помощь...» [16]. Однако в 40-х гг. это действительно оказывается особенно заметно в связи с обвинением, предъявленным Лангу, в производстве незаконных абортов: ему грозили суд и лишение практики - и все это время, вплоть до (благоприятного для Ланга) окончания процесса, письма его друга и бывшего пациента помогали ему выдерживать обрушившийся на него кошмар.

Читатель «Игры в бисер» способен увидеть здесь схему, уже знакомую ему по роману. Роман заканчивается тремя таинственными «жизнеописаниями», написанными (якобы) самим Иозефом Кнехтом. Проще всего увидеть в этих «жизнеописаниях» описание прежних его воплощений - «кудесника» Кнехта, «исповедника» Иозефуса Фамулюса (famulus - лат. «слуга», 
как и «кнехт» по-немецки), Дасы, ученика йога (даса - «слуга» на санскрите). Но нас сейчас особо интересует история Иозефуса Фамулюса: мягкий, добрый, молчаливый, он много лет провел в пустыне, принимая покаяния грешников и плача вместе с ними. («...все, что ему поверяли, казалось не брошенным на ветер, а преображенным, облегченным и разрешенным благодаря тому, что это сказано и услышано. Лишь изредка увещевал он и предостерегал, еще реже давал советы, а тем более приказывал; это, казалось, не было его обязанностью, и говорившие тоже, казалось, чувствовали, что это не его обязанность...» [1]). В конце концов Иозефуса настигает, как сказали бы сегодня, «профессиональное выгорание»: он слишком устал, он уже не чувствует себя достойным и способным исповедовать других - ему самому необходимо исповедаться... И Фамулюс отправляется искать знаменитого исповедника Диона Пугиля, методы которого коренным образом противоположны его собственным: Дион грозит и наказывает, грохочет и возглашает, накладывает кары и епитимьи. Каково же было удивление обоих исповедников, когда, случайно встретившись на пути, они узнают, что оба пустились в этот путь с одной и той же целью - найти один другого и один другому исповедаться... Здесь, возможно, мы имеем дело с «бродячим» сюжетом в духовной литературе. Во всяком случае, хорошо известен рассказ А.И. Куприна «Два святителя» с похожей фабулой - роль двух «исповедников» играют в нем Николай Угодник и Касьян (Кассиан Римлянин)...

Сделаем выводы.

Использование Германом Гессе в названии романа «Игра в бисер» слова «игра» вызвало многочисленные дискуссии о характере описываемого им общества: является ли деятельность «игроков в бисер» действительно лишь «игрой» интеллектуальной элиты или представляет собой практическое воплощение глубокой философской идеи, полезное для всего социума в целом; отсюда - и общий «фаустианский» пафос произведения.

Ассоциативное и этимологическое исследование главных имен собственных гессевского ономастикона (фамилии героя Кнехт и название утопической страны - Касталия) выявляет их «синтетический» характер, выразившийся в глубоком полисемантизме и неоднозначности возможной трактовки.

Имя Кнехта Иозеф, как мы предполагаем и обосновываем, могло быть «навеяно» не только эпопеей Т. Манна «Иосиф и его братья», но и тесной дружбой Гессе со своим терапевтом, учеником Юнга Йозефом Лангом.

\section{Лuтература}

1. Гессе Г. Игра в бисер. Опыт жизнеописания Иозефа Кнехта, магистра Игры, с приложением собственных его сочинений / пер. с нем. Д. Каравкиной и Вс. Розанова. М. : Художественная литература, 1969.317 с. [Электронный pecypc]. URL: http://www.isidor. ru/author/505/books/2894/gesse_german/igra_v_biser (дата обращения: 20.05.2016).

2. Ziolkowski T. Foreword. The Glass Bead Game (Magister Ludi) / By Hermann Hesse. Trans. Richard and Clara Winston. New York : Henry Holt and Co., Inc, 1969. 558 p.

3. Гессе Г. Начало всякого искусства есть любовь // Вступ. ст., сост. и примеч. Р. Каралашвили, пер. А. Михайлова // Вопросы литературы. 1978. № 9. С. 194-225.

4. Meier E. The Psychology of C.G. Jung in the Works of Hermann Hesse [Электронный pecypc]. URL: http://www.gss.ucsb.edu/projects/hesse/papers/maier.pdf (дата обращения: 21.05.2016). 
5. Бороденко Н.В. Символика Игры в бисер в новых контекстах романа Г. Гессе «Игра в бисер» // Известия Самарского научного центра РАН. 2012. Т. 14, №2 (4). С. 998-1001.

6. Бороденко Н.В. Противостояние двух миров в романе Г. Гессе «Игра в бисер»// Известия Самарского научного центра РАН. 2011. Т. 13, № 2(6). С. 1444-1446.

7. Малащенко B.B. Феномен игры в прозе Германа Гессе : «Демиан», «Кляйн и Вагнер», «Последнее лето Клингзора» : дис. ... канд. филол. наук. Калининград, 2008. 213 с. $832 \mathrm{c}$.

8. Фрэзер Дж. Дж. Золотая ветвь. Исследование магии и религии. М. : Политиздат, 1980.

9. Павсаний. Описание Эллады : в 2 т. Т. 2 / пер. С.П. Кондратьева; под ред. Е. Никитюк. М. : АСТ-Ладомир, 2002. 512 с.

10. Лосев А.Ф. Античная мифология в ее историческом развитии // Лосев А.Ф. Мифология греков и римлян. М. : Мысль, 1996. С. 11-681.

11. Hermann Hesse, Josef Bernhard Lang: «Die dunkle und wilde Seite der Seele». Briefwechsel mit seinem Psychoanalytiker Josef Bernhard Lang 1916-1945 / Hg. : Thomas Feitknecht. Frankfurt am Main : Suhrkamp, 2006. 426 p.

12. Канари Г.Ю. «Терапия творчеством» в жизни Германа Гессе // Психотерапия : ежемесячный рецензируемый научно-практический журнал. 2006. № 10. С. 28-31.

13. Клуб «Касталия» [Электронный pecypc]. URL: http://castalia.ru/ (дата обращения: 20.05.2016).

14. Сенэс Ж. Герман Гессе, или Жизнь Мага / Жаклин Сенэс, Мишель Сенэс; сер. ЖЗЛ. М. : Молодая гвардия, 2004. 277 с.

15. Гессе Г. Письма по кругу [пер. с нем.; сост., авт. предисл. и коммент. В. Д. Седельник]: Художественная публицистика. М. : Прогресс, 1987. 395 с.

16. Бауман Г. Герман Гессе и психология К.Г. Юнга [Электронный ресурс] / Гюнтер Бауман; доклад на IX Международном коллоквиуме, посвященном Гессе, Кальв, 1997. URL: https://www.hermannhesse.de/files/pdfs/ru_lebenskrise.pdf (дата обращения: 02.03.2016).

17. Гессе Г. Путешествие к земле Востока [пер. с нем. Е. В. Шукшиной] // Г. Гессе Сиддхартха; Путешествие к земле Востока [пер. с нем. Н.Н. Федоровой, Е.В. Шукшиной]. М. : Издво АCT, 2015. 224 c.

18. Ball H. Hermann Hesse. Sein Leben und Werk (erste bis vierte Auflage). Berlin, S. Fischer, 1927. $240 \mathrm{p}$.

19. Mileck J. Hermann Hesse: life and art. University of California Press, 1981. 397 p.

Elkan Olga B. Crimean State University of Culture, Arts and Tourism (Simferopol, Russian Federation).

E-mail: elkan.79@mail.ru

Tomsk State University Journal of Cultural Studies and Art History, 2017, № 25. 54-68 pp.

DOI: 10.17223/22220836/25/7

THE «SPEAKING» PRORER NAMES PHENOMENON IN THE ONOMASPHERE OF THE GERMAN SPEAKING CULTURE OF THE XX-th CENTURY (ON THE EXAMPLE OF H. HESSE'S NOVEL «THE GLASS BEAD GAME»)

Key words: German Speaking Culture, onomasphere, onomastikon, H. Hesse.

Hermann Hesse (1877-1962) was a German-born Swiss poet, novelist, and painter, Nobel Prize laureate (1946, Literature). “The Glass Bead Game” was Hesse's latest novel.

The main part of the novel is written in a genre of so-called "pseudo-biography", representing the detailed and plausible biography of the fictional character - Josef Knecht, "Master" of "The Glass Bead Game" who gave his name to all novel. Hesse used in the title of the novel the word "game" and caused numerous discussions about the character of the society by him described: is the activity of "players in beads" really only "the game" of intellectual elite or it represents the practical embodiment of a deep philosophical idea useful to all society? Thence - the general "Faustian" pathos of the novel.

The article conducted an associative and etymological research of the Hesse's "onomasticon" presented by the most important in the works of the author proper names - the surname of the main character of "The Glass Bead Game" Knecht and the name of the country of Castalia where the main events of the novel happen.

The Pedagogical Province of Goethe's novel "Wilhelm Meister's Apprenticeship" was the "literary prototype" and the classic prototype of Castalia. The mysterious "Ivory Tower» (die 
Turmgesellschaft) from the same novel became probably the "prototype" of the mysterious Castalia institution ...

The main character of the Hesse's novel - Joseph Knecht - "the elite pupil" of Castalia. "Der Knecht" is translated from German as "servant", but also has more derogative meanings - such as "lackey", "footman", "farm laborer", "slave". The author has embodied motive of "service" in Josef Knecht's character. Knecht is a faithful knight and the attendant of the citadel of Castalia (Kastell, castel, chastel, castle). It is significant, therefore, that Hesse determined by the main task of the real writer "to be an attendant, the lawyer and the knight of soul".

The author of the article carried out an "etymological excursus" and revealed the "synthetic" character of proper names expressed in the deep polysemantic and ambiguity of possible treatment.

The name of the character - Joseph - can be treated so ambiguously too. So, in addition to the popular hypothesis about the connection of the choice of the name of the protagonist with the T. Mann's epic "Joseph and his brothers" we assume and prove that H. Hesse has chosen for the favorite character the name of his close friend and therapist, C.-G. Yung' pupil - Joseph Lang.

It was the psychotherapist and close Hesse's friend Josef Lang who became the prototype for Pistorius in "Demian", astrologer Long in "Journey to the East", and - as we strongly believe - the protonym of Joseph Knecht in "The Glass Bead Game".

\section{References}

1. Hesse, H. (1969) Igra v biser. Opyt zhizneopisaniya Iozefa Knekhta, magistra Igry, s prilozheniem sobstvennykh ego sochineniy [The Glass Bead Game]. Translated from German by D. Karavkina \& Vs. Rozanova. Moscow: Khudozhestvennaya literature. [Online] Available from: http://www.isidor. ru/author/505/books/2894/gesse_german/igra_v_biser. (Accessed: 20th May 2016).

2. Ziolkowski, T. (1969) Foreword. In: Hesse, H. The Glass Bead Game (Magister Ludi). Translated by R. and C. Winston. New York: Henry Holt and Co.

3. Hesse, H. Nachalo vsyakogo iskusstva est' lyubov' [The Beginning of All Art is Love]. Translated from German by A. Mikhaylov. Voprosy literatury. 9. pp. 194-225.

4. Meier, E. (1999) The Psychology of C.G. Jung in the Works of Hermann Hesse. [Online] Available from: http://www.gss.ucsb.edu/projects/hesse/papers/maier.pdf. (Accessed: 21st May 2016).

5. Borodenko, N.V. (2012) The symbolism of the glass bead game in new contexts of novel by H. Hesse "The Glass Bead Game". Izvestiya Samarskogo nauchnogo tsentra RAN - Proceedings of the Samara Scientific Center of the Russian Academy of Science. 2(4). pp. 998-1001. (In Russian).

6. Borodenko, N.V. (2011) Protivostoyanie dvukh mirov v romane G. Gesse "Igra v biser" [Confrontation between the two worlds in H. Hesse's "The Glass Bead Game"]. Izvestiya Samarskogo nauchnogo tsentra RAN - Proceedings of the Samara Scientific Center of the Russian Academy of Science. 2(6). pp. 1444-1446.

7. Malashchenko, V.V. (2008) Fenomen igry v proze Germana Gesse : "Demian”, "Klyayn i Vagner", "Poslednee leto Klingzora" [The phenomenon of the game in the prose by Hermann Hesse: "Demian", "Klein and Wagner", "Last summer of Klingsor"]. Philology Cand. Diss. Kaliningrad.

8. Frazer, J.J. (1980) Zolotaya vetv'. Issledovanie magii i religii [The Golden Bough: A Study in Magic and Religion]. Translated from English by M.K. Ryklin. Moscow: Politizdat.

9. Pausanias. (2002) Opisanie Ellady: $v 2 t$. [The Description of Hellas: in 2 vols]. Vol. 2. Tranlsated by S.P. Kondratiev. Moscow: AST-Ladomir.

10. Losev, A.F. (1996) Mifologiya grekov i rimlyan [Mythology of the Greeks and Romans]. Moscow: Mysl'. pp. 11-681.

11. Hesse, H. \& Lang, J.B. (2006) "Die dunkle und wilde Seite der Seele". Briefwechsel mit seinem Psychoanalytiker Josef Bernhard Lang 1916-1945. Frankfurt am Main: Suhrkamp. (In German).

12. Kanarsh, G.Yu. (2006) "Terapiya tvorchestvom" v zhizni Germana Gesse ["Therapy with creativity" in the life of Hermann Hesse]. Psikhoterapiya: ezhemesyachnyy retsenziruemyy nauchnoprakticheskiy zhurnal. 10. pp. 28-31.

13. The Castalia Club. (n.d.) Klub "Kastaliya" [The Castalia Club]. [Online] Available from: http://castalia.ru/. (Accessed: 20th May 2016). 
14. Senes, J. \& Senes, M. (2004) German Gesse, ili Zhizn' Maga [Hermann Hesse, or The Life of the Magician]. Moscow: Molodaya gvardiya.

15. Hesse, H. (1987) Pis'ma po krugu [Letters in circles]. Translated from German by V.D. Sedelnik]. Moscow: Progress.

16. Bauman, G. (1997) German Gesse i psikhologiya K.G. Yunga [Hermann Hesse and Psychology of K.G. Jung]. [Online] Available from: https://www.hermannhesse.de/files/pdfs/ru_ lebenskrise.pdf. (Accessed: 2nd March 2016).

17. Hesse, H. (2015) Siddkhartkha; Puteshestvie k zemle Vostoka [Siddhartha; Journey to the East]. Translated from German by N.N. Fedorova, E.V. Shukshina. Moscow: AST.

18. Ball, H. (1927) Hermann Hesse. Sein Leben und Werk (erste bis vierte Auflage) [Hermann Hesse. His life and work (the first to fourth edition]. Berlin: S. Fischer.

19. Mileck, J. (1981) Hermann Hesse: life and art. University of California Press. 